\title{
A Stability-Indicating RP-HPLC-UV Method for Determination and Chemical Hydrolysis Study of a Novel Naproxen Prodrug
}

\author{
Mohamed H. M. Hamid ${ }^{1,2}$ and Tilal Elsaman ${ }^{1}$ \\ ${ }^{1}$ Department of Pharmaceutical Chemistry, College of Pharmacy, Omdurman Islamic University, P.O. Box 2587, \\ 11452 Khartoum, Sudan \\ ${ }^{2}$ Department of Pharmaceutical Chemistry, College of Pharmacy, University of Medical Sciences and Technology, \\ P.O. Box 12810, Khartoum, Sudan \\ Correspondence should be addressed to Mohamed H. M. Hamid; drholo2@gmail.com
}

Received 9 April 2017; Revised 7 August 2017; Accepted 17 August 2017; Published 25 October 2017

Academic Editor: Orazio Nicolotti

Copyright (C) 2017 Mohamed H. M. Hamid and Tilal Elsaman. This is an open access article distributed under the Creative Commons Attribution License, which permits unrestricted use, distribution, and reproduction in any medium, provided the original work is properly cited.

\begin{abstract}
A new naproxen amide prodrug was synthesized and spectrally characterized and a simple, precise, and accurate stabilityindicating RP-HPLC method was developed and validated for determination and chemical hydrolysis study of the prodrug. Forced degradation studies were conducted as per the International Conference on Harmonization (ICH) guidelines to establish the stability-indicating power of the method. Separations were performed on a $\mathrm{C}_{18}$ column $(150 \times 4.6 \mathrm{~mm}$ i.d., $5 \mu \mathrm{m}$ p.s. $)$. The mobile phase consisted of acetonitrile and phosphate buffer pH 4.0 in the ratio $60: 40$. The flow rate and injection volume were $1.0 \mathrm{~mL} / \mathrm{min}$ and $15 \mu \mathrm{L}$, respectively. The peaks were monitored at $272 \mathrm{~nm}$. The average retention time is $5.136 \mathrm{~min}$. The linearity of the method was investigated in the range of $10-50 \mu \mathrm{g} / \mathrm{mL}$ and $r^{2}$ was found to be larger than 0.9987 . The LOD and LOQ were found to be 1.853 and $5.615 \mu \mathrm{g} / \mathrm{mL}$, respectively. Results indicated that the degradants are well resolved and separated from the prodrug. Hydrolysis kinetics studies were carried out in buffer solutions ( $\mathrm{pH}$ 1.2, 5.5 and 7.4) to establish the fate of the prodrug. The half-lives in the respective buffers were $23.5,262$, and 334 hours indicating sufficient stability to attain the goal of oral delivery.
\end{abstract}

\section{Introduction}

A prodrug is a modified biologically active compound that will release the active compound in vivo following enzymatic or chemical cleavage. Many drugs have unwanted properties that hinder their clinical use, such as susceptibility to acid hydrolysis in the stomach, causing damage to the stomach itself. There are many approaches to overcome those problems such as coating, different formulations, and different routes of administration. However, chemical derivatization of the drug into a prodrug remains the most common approach $[1,2]$. Nonsteroidal anti-inflammatory drugs (NSAIDs) are the most commonly used agents for the symptomatic relief of fever, minor inflammations, headaches, swelling, sports related pains, and arthritis pain. They are also very helpful in postoperative, menstrual, and dental pains. Individually, they have different characteristics, but all of them share one pharmacological activity in-common, which is their ability to inhibit the cyclooxygenase (COX) enzyme family.
COX enzymes have many isoforms, but only two are well studied. They are COX-1 and COX-2. COX-1 is responsible for prostaglandins generation, which have cytoprotective effects on the stomach. COX-2 is mainly activated by inflammation. Therefore, most of the anti-inflammatory, antipyretic, and analgesic effects of the NSAIDs are attributed to their inhibition of COX-2, while most of their side effects can be related to inhibition of COX-1. Because NSAIDs are almost always used chronically especially by the elderly, their dangerous gastrointestinal (GI), cardiac, and renal side effects constitute a problem hindering their use. The prodrug approach is an effective way to mask the carboxylic acid group of NSAIDs, which is the main culprit in the GI adverse effects $[3,4]$.

Naproxen is a NSAID of the phenylpropanoic acid class just like ibuprofen. Its GI toxic side effects are intermediate between ibuprofen (low) and indomethacin (high). Its structure is enantiomeric, which is (+)-2-(6-methoxy2-naphthyl)-propanoic acid (Figure 1) [5]. Naproxen (NP) still has all the side effects of NSAIDs; therefore, naproxen 
<smiles>COc1ccc2cc([C@@H](C)C(=O)O)ccc2c1</smiles>

FIGURE 1: Chemical structure of S-naproxen.<smiles>CCCOC(=O)CNC(=O)[C@H](C)c1ccc2cc(OC)ccc2c1</smiles>

Figure 2: Chemical structure of pro-NP.

prodrugs were studied. Ester and amide prodrugs are the most studied prodrugs of naproxen. Studies show that they do reduce the GI adverse reactions of naproxen significantly $[2,5-7]$.

Quite a lot of different naproxen prodrugs were synthesized and reported in the literature $[5,6,8-15]$. However, the naproxen prodrug understudy here (referred to here after as pro-NP, Figure 2) contains and will release glycine in vivo which is not only safe but useful as a nutrient for the body. Furthermore, the intermediate of the synthesis of pro-NP is reported in the literature [16] to possess pharmacological activities. Microwave-assisted transesterification was used here for the first time to synthesize a naproxen prodrug. This reduces the transesterification time significantly and enhances the lipophilicity of the resulting prodrug which is crucial for oral activity.

Stability-indicating methods were described in the literature to study the chemical hydrolysis of naproxen prodrugs $[12,13,15,17-19]$. Most of them employed HPLC with UV detection and $\mathrm{C}_{18}$ columns for its simplicity the same as in the method below. However, Rautio et al. [13] used a fluorescence detector and Sheha et al. [15] used a $\mathrm{C}_{8}$ column.

In light of the above and in continuation of our interest to synthesize a GI sparing NSAIDs prodrugs [2, 20], a new amide prodrug of naproxen (pro-NP) was synthesized and spectrally characterized and a validated stability-indicating RP-HPLC method was developed for studying the chemical stability of pro-NP.

\section{Materials and Methods}

2.1. General. S-Naproxen and ethyl glycinate were purchased from Sigma-Aldrich. Microwave reactor (CEM, USA) was used in final synthesis step. The reaction was monitored by
TLC on precoated silica G plates using UV lamps. Melting point was determined on a Gallenkamp melting point apparatus and is uncorrected. Infrared (IR) Spectrum was recorded as $\mathrm{KBr}$ disc using the Perkin Elmer FT-IR Spectrum BX apparatus located at the Research Center, College of Pharmacy, King Saud University (Riyadh, Saudi Arabia). NMR spectrum was scanned in DMSO-d6 on a Bruker NMR spectrometer operating at $500 \mathrm{MHz}$ for ${ }^{1} \mathrm{H}$ and $125.76 \mathrm{MHz}$ for ${ }^{13} \mathrm{C}$ at the Research Center, College of Pharmacy, King Saud University (Riyadh, Saudi Arabia). Chemical shifts are expressed in $\delta$-values (ppm) relative to TMS as an internal standard. Coupling constants $(J)$ are expressed in $\mathrm{Hz}$. $\mathrm{D}_{2} \mathrm{O}$ was added to confirm the exchangeable protons. Mass spectra were measured on Agilent Triple Quadrupole 6410 QQQ LC/MS with ESI (Electrospray ionization) source. The acetonitrile $R S$ used was HPLC grade, was purchased from Carlo Erba Reagents S.A.S. (F-27106 Val-de-Reuil Cedex, France), and was used without further purification. All other reagents used were of analytical grade.

2.2. Synthesis. Pro-NP was synthesized by coupling of Snaproxen with glycine ethyl ester hydrochloride using DCC as coupling agent according to the literature method [2] (Scheme 1). The resulting intermediate was further subjected to microwave-assisted transesterification reaction in propanol using potassium cyanide as catalyst for five minutes. The final product was purified by column chromatography using hexane : ethyl acetate as mobile phase.

2.3. Chromatographic Conditions. The HPLC method was developed on a Shimadzu prominence UFLC system (Shimadzu corporation, Kyoto, Japan) that consisted of a UV/Vis detector (SPD-20AV), a degasser (DGU-20A3R), column 
<smiles>COc1ccc2cc([C@@H](C)C(=O)O)ccc2c1</smiles>

(S)-Naproxen<smiles>CC(C)(C)CCCOC(=O)CN</smiles>

Ethyl glycinate

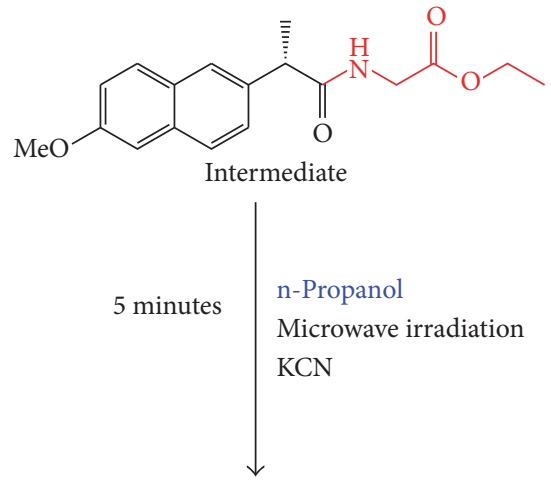<smiles>CCCOC(=O)CNC(=O)[C@H](C)c1ccc2cc(OC)ccc2c1</smiles>

Pro-NP

SCHeme 1: Synthesis of the targeted pro-NP.

oven (CTO-20A), and a pump (LC-20AB). The column used was $\mathrm{C}_{18}(150 \times 4.6 \mathrm{~mm}$ internal diameter, $5 \mu \mathrm{m}$ particle size $)$ at ambient temperature. Isocratic elution was used with the mobile phase consisting of acetonitrile and phosphate buffer $\mathrm{pH} 4.0$ in the ratio $60: 40$. The flow rate and injection volume were $1.0 \mathrm{~mL} / \mathrm{min}$ and $15 \mu \mathrm{L}$, respectively. The peaks were monitored at the wavelength of $272 \mathrm{~nm}$. The average retention time is $5.136 \mathrm{~min}$.

2.4. Preparation of Standard Stock Solution. A standard stock solution of pro-NP $(100 \mu \mathrm{g} / \mathrm{mL})$ was prepared by dissolving accurately weighed $10 \mathrm{mg}$ of the drug in $100 \mathrm{~mL}$ methanol.

2.5. Preparation of Phosphate Buffer $p H$ 4.0. $6.80 \mathrm{~g}$ of $\mathrm{KH}_{2} \mathrm{PO}_{4}$ was dissolved in $700 \mathrm{~mL}$ of water. Then the $\mathrm{pH}$ was adjusted when necessary with $10 \% \mathrm{v} / \mathrm{v} \mathrm{H}_{3} \mathrm{PO}_{4}$. Water was added to complete to $1000 \mathrm{~mL}$ (BP 2013).

2.6. Forced Degradation Stability Studies/Specificity. Forced degradation stability study was conducted as per ICH guidelines Q1A (R2) [21] and Q1B [22], regarding hydrolytic degradation, thermal degradation, photolytic degradation, and oxidative degradation. Results for forced degradation study are shown in Table 2 .

2.6.1. Acidic and Alkaline Hydrolytic Degradation Study. For the acid hydrolysis study, $2 \mathrm{~mL}$ of the pro-NP stock solution was transferred to a $20 \mathrm{~mL}$ volumetric flask and was completed up to the mark with $0.1 \mathrm{~N} \mathrm{HCl}$. A blank solution was also prepared. A determination of both solutions was made at zero time and after $24 \mathrm{~h}$. For the base hydrolysis study, $2 \mathrm{~mL}$ separately of the pro-NP stock solution was transferred to two $20 \mathrm{~mL}$ volumetric flasks and completed up to the mark with $0.1 \mathrm{~N}$ and $0.01 \mathrm{~N} \mathrm{NaOH}$. Two blank solutions were made. A determination of all four solutions was made at only zero time.
2.6.2. Oxidative Degradation Study. $2 \mathrm{~mL}$ of the pro-NP stock solution was transferred to a $20 \mathrm{~mL}$ volumetric flask and made up to the mark with $3 \% \mathrm{H}_{2} \mathrm{O}_{2}$ and an aliquot was injected into the HPLC at zero time and after $24 \mathrm{~h}$. In another flask, $2 \mathrm{~mL}$ of the pro-NP stock solution was made to the mark with $6 \% \mathrm{H}_{2} \mathrm{O}_{2}$ and put in an oven set at $50^{\circ} \mathrm{C}$ for $2 \mathrm{~h}$ and then an aliquot was injected into the HPLC. Blanks were made and analyzed.

2.6.3. Thermal Degradation Study. The solid pro-NP drug was put in an oven set at $70^{\circ} \mathrm{C}$ and an appropriate amount was taken, dissolved in methanol, and injected into the HPLC after $24 \mathrm{~h}$ and another after $48 \mathrm{~h}$.

2.6.4. Photolytic Degradation Study. The solid pro-NP drug was subjected to different lamps that emit visible light, short UV, and long UV. After two days, an appropriate amount was taken, dissolved in methanol, and injected into the HPLC.

2.7. Method Validation. The proposed method was validated as per ICH guidelines [23] with respect to linearity, specificity, accuracy, precision, LOD, LOQ, and robustness.

2.7.1. Specificity (Selectivity). In addition to forced degradation studies specificity was also confirmed by spiking pro$\mathrm{NP}$ with naproxen (NP), which is a known degradant of pro-NP. $10 \mathrm{mg}$ of naproxen $R S(\mathrm{NP})$ was dissolved in $100 \mathrm{~mL}$ of methanol to give $100 \mu \mathrm{g} / \mathrm{mL}$ stock solution of NP. $2 \mathrm{~mL}$ of the NP stock solution was mixed with $4 \mathrm{~mL}$ of pro-NP stock solution and completed to $20 \mathrm{~mL}$ with methanol and an aliquot of the mixture was injected into the HPLC. The resolution $\left(R_{s}\right)$ between the two peaks was calculated.

2.7.2. Linearity. The standard solutions for the estimation of linearity were prepared as per Table 1. Standard solutions used in the estimation of linearity (calibration curve) were 
TABLE 1: Preparation of standard solutions for the evaluation of linearity.

\begin{tabular}{lcc}
\hline $\begin{array}{l}\text { Concentration } \\
(\mu \mathrm{g} / \mathrm{mL})\end{array}$ & $\begin{array}{c}\text { Volume pipetted } \\
\text { from the stock } \\
(\mathrm{mL})\end{array}$ & $\begin{array}{c}\text { Volume } \\
\text { made up to } \\
(\mathrm{mL})\end{array}$ \\
\hline 10 & 2 & 20 \\
15 & 3 & 20 \\
20 & 4 & 20 \\
25 & 5 & 20 \\
30 & 6 & 20 \\
50 & 10 & 20 \\
\hline
\end{tabular}

TABLE 2: Results of forced degradation stability studies.

\begin{tabular}{lccccc}
\hline Stress condition & Nature of pro-NP & Number of determinations & Time (hours) & Temperature $\left({ }^{\circ} \mathrm{C}\right)$ & Degradation $(\%)$ \\
\hline Hydrolysis, acidic & Solution & In $0.1 \mathrm{~N} \mathrm{HCl}$ & 24 & 25 & 21.5 \\
\hline \multirow{2}{*}{ Hydrolysis, alkali } & \multirow{2}{*}{ Solution } & In $0.1 \mathrm{~N} \mathrm{NaOH}$ & 0 & 25 & 100 \\
& & In $0.01 \mathrm{~N} \mathrm{NaOH}$ & 0 & 25 & 100 \\
\hline \multirow{3}{*}{ Oxidation } & \multirow{3}{*}{ Solution } & In $3 \% \mathrm{H}_{2} \mathrm{O}_{2}$ & 24 & 25 & 0 \\
& & In $3 \% \mathrm{H}_{2} \mathrm{O}_{2}$ & 24 & 50 & 0 \\
\hline Thermal & Solid & In $6 \% \mathrm{H}_{2} \mathrm{O}_{2}$ & 2 & 40 & 0 \\
\hline Photolytic & Solid & Once & 48 & 25 & 0 \\
\hline
\end{tabular}

TABLE 3: Data from the regression analysis.

\begin{tabular}{lc}
\hline Parameter & Pro-NP \\
\hline Linearity range & $10-50 \mu \mathrm{g} / \mathrm{mL}$ \\
Slope & 19173.985 \\
Intercept & -1695.79167 \\
Regression coefficient $R^{2}$ & 0.998740 \\
Regression equation & $y=19174 x-1695.8$ \\
LOQ & $5.61457116 \mu \mathrm{g} / \mathrm{mL}$ \\
LOD & $1.852808483 \mu \mathrm{g} / \mathrm{mL}$ \\
\hline
\end{tabular}

prepared by suitable dilutions from the pro-NP stock solution to attain solutions of different concentrations. A plot of the peak area versus the concentration of the standard solutions was made (Figure 7). Regression analysis was carried out on the plot. From the regression data, the correlation coefficient $\left(r^{2}\right)$, the slope of the line, the $Y$-intercept, and line equation were calculated in Table 3.

2.7.3. Precision. Precision has been established in three steps: assessment of repeatability, interday precision assessment, and intraday precision assessment.

2.7.4. Robustness. Small but deliberate changes were made to the mobile phase $\mathrm{pH}$, which is 4.0 , and the detection wavelength, which is $272 \mathrm{~nm}$. Twelve determinations were made as follows: 3 at $270 \mathrm{~nm}, 3$ at $274 \mathrm{~nm}, 3$ at pH 4.3, and 3 at $\mathrm{pH}$ 3.7. The $\%$ RSD was calculated for the determinations at the changed parameters with the determinations at the normal parameter.

2.7.5. $L O D$ and LOQ. The LOD and LOQ were calculated from the equations

$$
\begin{aligned}
& \mathrm{LOD}=\frac{3.3 \sigma}{s}, \\
& \mathrm{LOQ}=\frac{10 \sigma}{s},
\end{aligned}
$$

where $\sigma$ is the standard deviation of the responses and $s$ is the slope of the calibration curve.

2.8. Determination of the Hydrolysis Reaction Kinetics In Vitro. Chemical hydrolysis was studied at $37^{\circ} \mathrm{C} \pm 1^{\circ} \mathrm{C}$ in $\mathrm{pH} 1.2$ (SGF), pH 5.5 phosphate solution (duodenal $\mathrm{pH}$ ), and $\mathrm{pH}$ 7.4. Each reaction was initiated by taking $3 \mathrm{~mL}$ of the stock methanolic solution of pro-NP, to $20 \mathrm{~mL}$ volumetric flask, one drop of Tween- 80 was added, and the volume completed to the mark with the buffer solution of the intended $\mathrm{pH}$. The solutions were transferred to screw-capped test tubes. Samples were taken at appropriate time intervals spread over eight hours and chromatographed and the residual concentrations were calculated. 


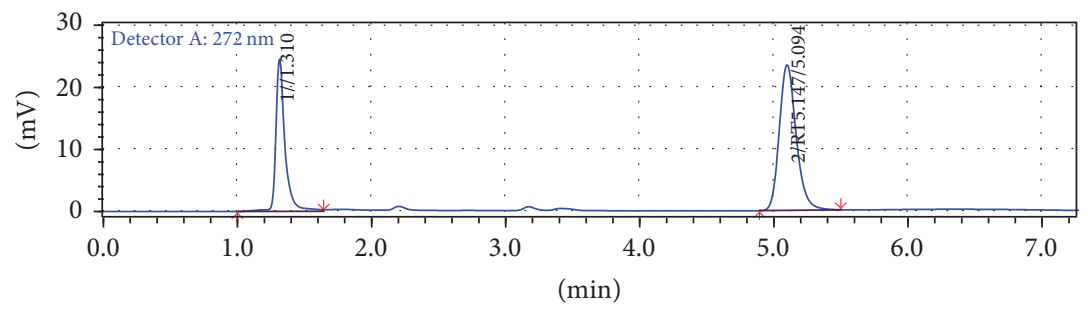

(a)

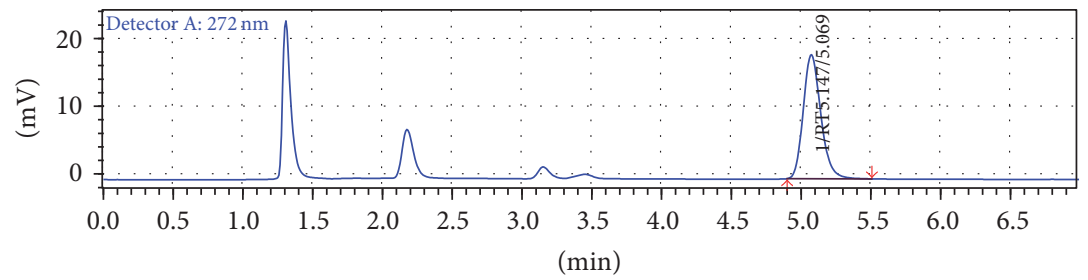

(b)

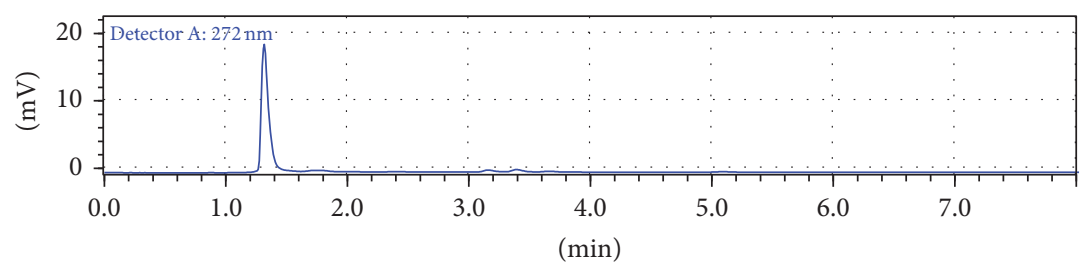

(c)

Figure 3: Chromatograms indicating acid hydrolysis degradation of pro-NP. (a) is the chromatogram of pro-NP in $0.1 \mathrm{~N}$ HCl at zero time. (b) is the chromatogram of pro- $\mathrm{NP}$ in $0.1 \mathrm{~N} \mathrm{HCl}$ after $24 \mathrm{~h}$. (c) is the chromatogram of a blank in the same study.

\section{Results and Discussion}

3.1. Spectral Data for the Intermediate. White powder; yield (76\%), m.p. $\left(84-86^{\circ} \mathrm{C}\right)$. IR (KBr): $v_{\max } / \mathrm{cm}^{-1} 3360(\mathrm{NH})$, $1713\left(\mathrm{C}=\mathrm{O}\right.$, ester), 1669 ( $\mathrm{C}=\mathrm{O}$, amide). ${ }^{1} \mathrm{H}$ NMR: $\left(\mathrm{CDCl}_{3}\right)$ $\delta 1.23\left(\mathrm{t}, 3 \mathrm{H}, J=7.0 \mathrm{~Hz},-\mathrm{OCH}_{2} \mathrm{CH}_{3}\right), \delta 1.64(\mathrm{~d}, 3 \mathrm{H}, J=$ $\left.7 \mathrm{~Hz},-\mathrm{CHCH}_{3}\right), \delta 3.76-3.79\left(\mathrm{q}, \mathrm{CHCH}_{3}\right), 3.94-4.05(\mathrm{~m}, 5 \mathrm{H}$, $-\mathrm{OCH}_{3}$ and $\mathrm{NHCH}_{2}$ ), 4.15-4.19 (q, 2H, J = 7.0 Hz, OCH $\left.\mathrm{OH}_{2}\right), 5.9$ (s, 1H, NH, $\mathrm{D}_{2} \mathrm{O}$-exchangeable) 7.14-7.19 (m, 2H, ArH), 7.43 (d, $1 \mathrm{H}, J=8 \mathrm{~Hz}, \operatorname{ArH}), 7.72-7.76(\mathrm{~m}, 3 \mathrm{H}, \operatorname{ArH}) .{ }^{13} \mathrm{C}$ NMR: $\delta 14.08\left(\mathrm{OCH}_{2} \mathrm{CH}_{3}\right), 18.4\left(\mathrm{CHCH}_{3}\right), 41.5\left(\mathrm{NHCH}_{2}\right), 46.8$ $\left(-\mathrm{CHCH}_{3}\right), 55.3\left(-\mathrm{OCH}_{3}\right), 61.4\left(\mathrm{O}-\mathrm{CH}_{2} \mathrm{CH}_{3}\right), 105.6,119.18$, $126.28,127.59,128.99,129.62,133.81,136.02,157.77$ (Ar-C), 169.85 ( $-\mathrm{C}=\mathrm{O}$ amide), $174.44(-\mathrm{C}=\mathrm{O}$ ester $)$. MS-ESI: $m / z$ $315.6\left(\mathrm{M}^{+}\right)$.

3.2. Spectral Data for Pro-NP. White powder; yield (90\%), m.p. $\left(72-75^{\circ} \mathrm{C}\right)$. Microwave condition: $T^{\circ}=150^{\circ} \mathrm{C}$, power $=200$ wat, pressure $=247 \mathrm{psi}$, time $=5$ minute. IR $(\mathrm{KBr})$ : $\nu_{\max } / \mathrm{cm}^{-1} 3311(\mathrm{NH}), 1730(\mathrm{C}=\mathrm{O}$, ester $), 1640(\mathrm{C}=\mathrm{O}$, amide $)$. ${ }^{1} \mathrm{H} \mathrm{NMR}:\left(\mathrm{CDCl}_{3}\right) \delta 0.91\left(\mathrm{t}, 3 \mathrm{H}, J=7.0 \mathrm{~Hz},-\mathrm{OCH}_{2} \mathrm{CH}_{2} \mathrm{CH}_{3}\right)$, $\delta$ 1.59-1.65 (m, 5H, $-\mathrm{CHCH}_{3}$ and $\left.-\mathrm{CH}_{2} \mathrm{CH}_{3}\right), \delta$ 3.76-3.79 $\left(\mathrm{q}, 1 \mathrm{H}, \mathrm{CHCH}_{3}\right), 3.94-4.05\left(\mathrm{~m}, 7 \mathrm{H},-\mathrm{OCH}_{3}, \mathrm{NHCH}_{2}\right.$ and $\left.-\mathrm{OCH}_{2}\right), 5.9\left(\mathrm{~s}, 1 \mathrm{H}, \mathrm{NH}, \mathrm{D}_{2} \mathrm{O}\right.$-exchangeable) $7.14-7.19(\mathrm{~m}, 2 \mathrm{H}$, $\operatorname{ArH}), 7.43$ (d, 1H, $J=8 \mathrm{~Hz}, \operatorname{ArH}), 7.72-7.76$ (m, 3H, ArH). ${ }^{13} \mathrm{C}$ NMR: $\delta 10.25\left(\mathrm{OCH}_{2} \mathrm{CH}_{2} \mathrm{CH}_{3}\right), 18.4\left(\mathrm{CHCH}_{3}\right), 21.83$
$\left(\mathrm{OCH}_{2} \mathrm{CH}_{2} \mathrm{CH}_{3}\right), 41.48\left(\mathrm{CH}_{2} \mathrm{NH}-\right), 46.88\left(-\mathrm{CHCH}_{3}\right), 55.34$ $\left(-\mathrm{OCH}_{3}\right), 67.00\left(\mathrm{O}-\mathrm{CH}_{2} \mathrm{CH}_{3}\right), 105.65,119.19,126.29,127.61$, $129.00,129.26,133.82,136.00,157.78$ (Ar-C), $169.92(-\mathrm{C}=\mathrm{O}$ amide), 174.42 ( $-\mathrm{C}=\mathrm{O}$ ester). MS-ESI: $m / z 330.3(\mathrm{M}+1)$. MSEI: $m / z 330.3(\mathrm{M}+1)(1 \%), 329.2\left(\mathrm{M}^{+}\right)(10 \%), 270(1 \%), 242$ (1\%), 212 (2\%), 186 (21\%), 185 (100\%), 171 (9\%), 169 (12\%), 155.1 (3\%), 152 (8\%), 140.9 (11\%), 114.9 (7\%), 74 (5\%), 55.9 (2\%).

3.3. Results of Forced Degradation Stability Studies/Specificity. During the forced degradation studies, the peaks of proNP were found to be pure and no significant degradation of drug substance was observed in thermal, photolytic, and oxidative conditions (Table 2). During the acidic hydrolysis analysis in $0.1 \mathrm{~N} \mathrm{HCl}$ and after $24 \mathrm{~h}$, a $21.5 \%$ degradation occurred (Figure 3). The guidelines [21, 22] consider that amount of degradation is enough to be representative of all possible acidic hydrolysis degradation. The two possible acidic degradation products are (2-(6-methoxynaphthalen2 -yl) propanoyl)glycine $\left(R_{t}=2.4 \mathrm{~min}\right)$ and naproxen $\left(R_{t}\right.$ $=3.6 \mathrm{~min}$ ) (illustrated in Figure 5). Moreover, during the alkaline hydrolysis analysis in both $0.1 \mathrm{~N}$ and $0.01 \mathrm{~N} \mathrm{NaOH}$ at zero time, complete degradation of the drug substance occurred (Figure 4). This can only be explained by the breakdown of the ester bond in pro-NP and the formation of a soluble sodium salt. Furthermore, alkaline hydrolysis of esters is irreversible. 


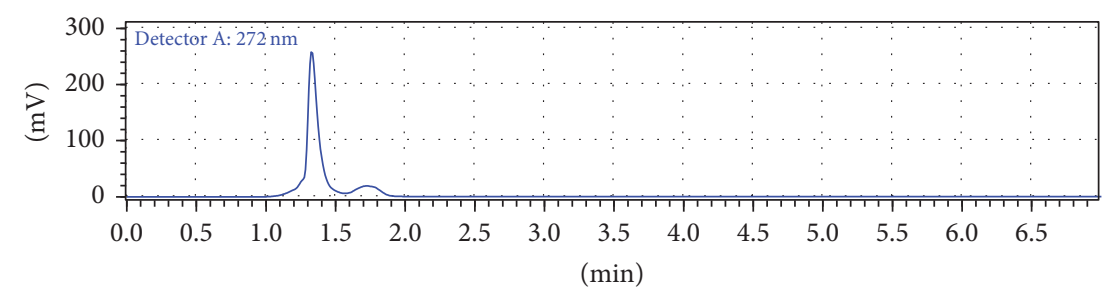

(a)

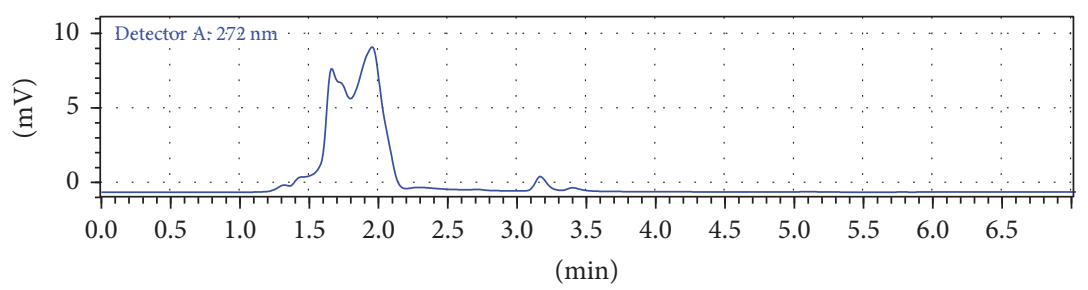

(b)

FIGURE 4: Chromatograms showing the complete degradation of pro-NP in (a) $0.1 \mathrm{~N} \mathrm{NaOH}$ and (b) $0.01 \mathrm{~N} \mathrm{NaOH}$.

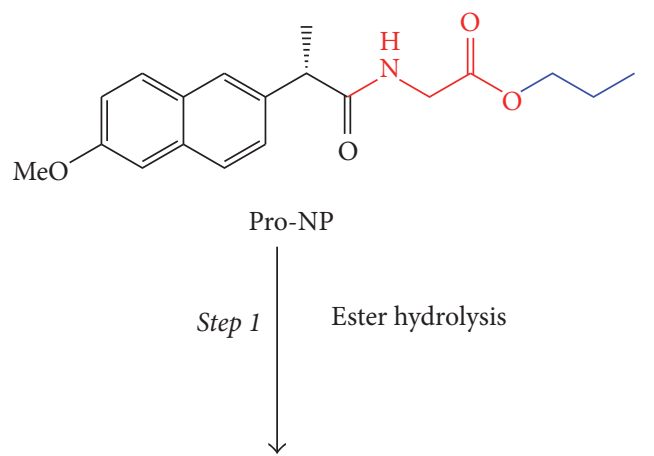<smiles>COc1ccc2cc([C@@H](C)C(=O)NCC(=O)O)ccc2c1</smiles><smiles>COc1ccc2cc([C@@H](C)C(=O)O)ccc2c1</smiles>

(S)-Naproxen

FIGURE 5: The degradation pathway of pro-NP.

\subsection{Results of Method Validation}

3.4.1. Specificity (Selectivity). NP is an expected degradation product of pro-NP. NP seems to be the peak that elutes the closest to the drug peak; therefore, a mixture of NP : pro-NP in the ratio of $1: 2$ was prepared and injected into the HPLC. Through visual inspection alone, the observer can determine that those two peaks are well resolved; $R_{S}>1.5$ (Figure 6). 
TABLE 4: Data from the precision evaluation.

\begin{tabular}{|c|c|c|c|c|c|}
\hline \multirow{2}{*}{ Experiment number } & \multicolumn{4}{|c|}{ Peak areas } & \multirow{2}{*}{$\%$ RSD } \\
\hline & Repeatability & Day 1 & Day 2 & Day 3 & \\
\hline 1 & 482726 & 483990 & 494994 & 483664 & 1.322806 \\
\hline 2 & 467668 & 486134 & 494258 & 495749 & 1.051686 \\
\hline 3 & 473884 & 467312 & 487120 & 493997 & 2.869627 \\
\hline 4 & 480740 & 468877 & 491463 & 486034 & 2.445337 \\
\hline 5 & 469853 & 483700 & 488475 & 496976 & 1.373156 \\
\hline 6 & 477899 & 481472 & 490697 & 484151 & 0.9776 \\
\hline \multirow{2}{*}{$\% R S D$} & & & & & 1.67 \\
\hline & 1.266338 & 1.728179 & 0.631699 & 1.250237 & 1.2 \\
\hline
\end{tabular}

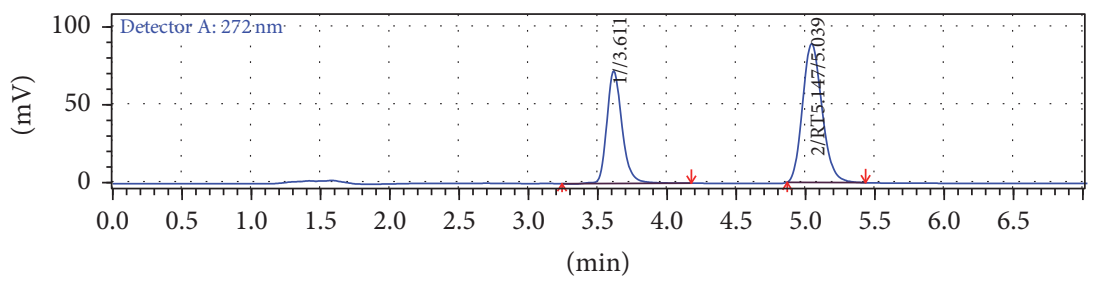

FIGURE 6: A chromatogram indicating the resolution between pro-NP and NP.

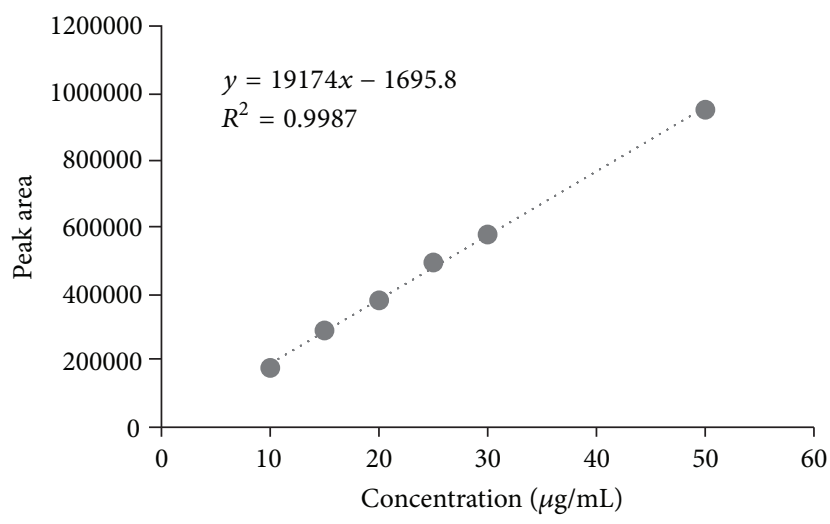

FIGURE 7: Calibration curve.

3.4.2. Linearity. The linearity of the method was determined at six concentration levels. A plot of peak area $(Y)$ against concentration $(X, \mu \mathrm{g} / \mathrm{mL})$ was drawn for pro-NP standard solutions with $10,15,20,25,30$, and $50 \mu \mathrm{g} / \mathrm{mL}$ concentrations. The results revealed an excellent correlation between the peak area and analyte concentration, as evident by the coefficient of determination, $r^{2}$, which is greater than 0.9987 . The calibration curve and its results are presented in Figure 7 and Table 3, respectively.

3.4.3. Precision. The first step in establishing precision was repeatability. The $\%$ RSD of repeatability was 1.266 . The $\%$ RSD of the intraday precision evaluation was 1.203 , while that of interday precision was 1.673 . The $\%$ RSD values of the repeatability, intraday, and interday studies were all $<2$, confirming that the method is precise. Calculations of the precision data are presented in Table 4.

3.4.4. Robustness. In all the deliberately varied chromatographic conditions (mobile phase $\mathrm{pH}$ and the detection
TABle 5: System suitability data.

\begin{tabular}{lc}
\hline Parameter & Value \\
\hline Theoretical plates & 5822.588 \\
Tailing factor & 1.211 \\
Resolution & 1.586 \\
Capacity factor & 5.039 \\
\hline
\end{tabular}

wavelength), the developed method showed satisfactory resolution $(\%$ RSD $<2$ ), illustrating the robustness of the method (Table 6).

3.4.5. Accuracy. The accuracy was accepted based on the results of the linearity, precision, and sensitivity studies. This approach is accepted and justified by the ICH guidelines [23].

3.4.6. System Suitability. System suitability data are calculated in Table 5. 


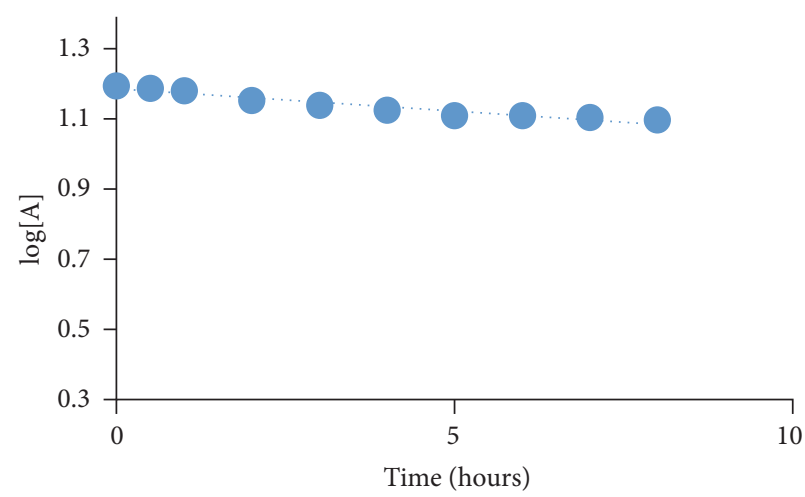

(a)

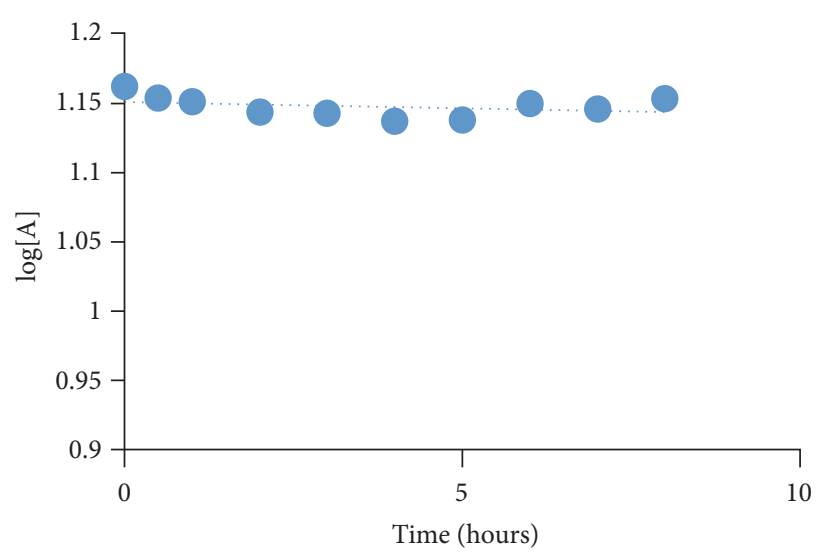

(c)

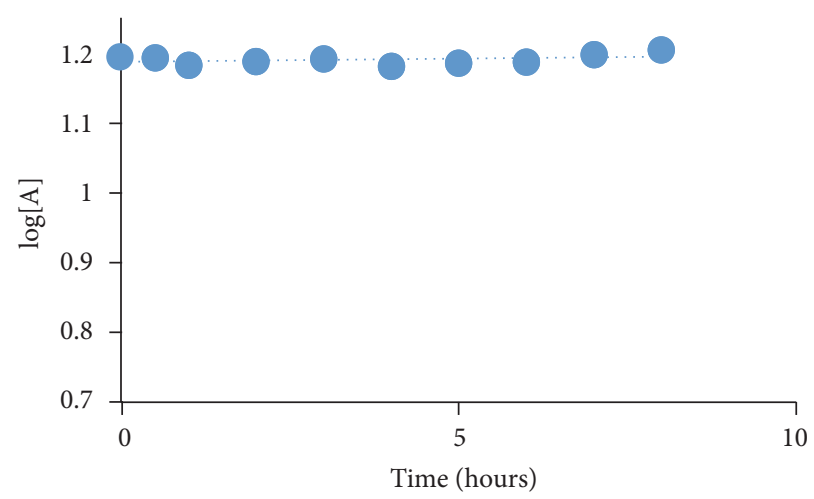

(b)

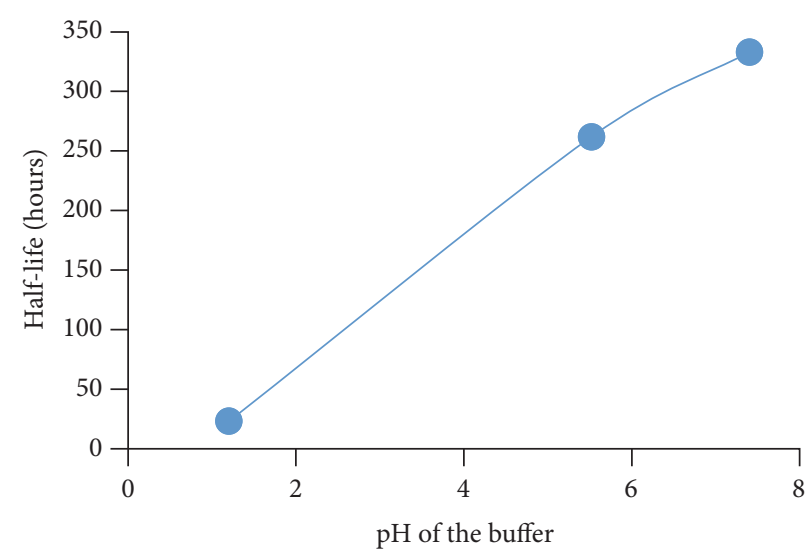

(d)

FIGURE 8: Hydrolysis of pro-NP in (a) SGF, (b) $\mathrm{pH}$ 7.4, and (c) $\mathrm{pH}$ 5.5. (d) is $t_{1 / 2}$ of pro-NP in different buffer solutions.

TABLE 6: Robustness analysis.

\begin{tabular}{lcc}
\hline \multirow{2}{*}{ Parameter } & \multicolumn{2}{c}{ Peak areas } \\
& $\mathrm{pH}$ & Wavelength \\
\hline Normal (pH 4.0, 272 nm detection) & 576794 & 576794 \\
\hline \multirow{2}{*}{ Change 1 (pH 3.7, 270 nm detection) } & 597818 & 588379 \\
& 596622 & 585239 \\
& 598154 & 602703 \\
\hline \multirow{2}{*}{ Change 2 (pH 4.3, 274 nm detection) } & 599370 & 577334 \\
& 598128 & 573709 \\
\hline \% RSD & 596365 & 576894 \\
\hline
\end{tabular}

3.5. Results of the Hydrolysis Study. The hydrolysis kinetics studies were carried out in aqueous buffer solutions $(\mathrm{pH} 1.2$, 5.5, and 7.4) to establish the fate of the synthesized pro-NP. Under the experimental conditions, the targeted compound hydrolyzed to release the parent drug (NP) as evident by $\mathrm{HPLC}$ analysis. At constant $\mathrm{pH}$ and temperature, the reaction exhibited first-order kinetics, since plots of log concentration versus time resulted in straight lines (Figure 8 ). The rate constants $\left(K_{\mathrm{obs}}\right)$ and the corresponding half-lives $\left(t_{1 / 2}\right)$ for the prodrug were calculated (Tables 7 and 8 ). The half-life was calculated using the equation $t_{1 / 2}=0.693 / \mathrm{K}$, which derives from the first-order kinetic law. In SGF, more than $20 \%$ of pro-NP was hydrolyzed after $8 \mathrm{~h}$. In $\mathrm{pH} 7.4$, only $2 \%$ of the drug was hydrolyzed after $8 \mathrm{~h}$. In pH 5.5, the drug was found intact after $8 \mathrm{~h}$, indicating complete absence of hydrolysis at that $\mathrm{pH}$. The pro-NP was found to be stable in all investigated GI fluids with half-lives more than 20 hours which confirm that this prodrug will pass intact through GIT; when reaching the systemic circulation, a reasonable degradation will take place by nonspecific esterases and amidases in the liver to liberate the parent drug NP.

\section{Conclusion}

The method developed is simple, accurate, precise, specific, and robust. Forced degradation and spiking with degradants showed that the degradants are well resolved and separated from the prodrug. Pro-NP is therefore suitable to attain the goals of oral administration since it is stable during its passage through GIT. 
TABLE 7: The results from the hydrolysis kinetics.

\begin{tabular}{|c|c|c|c|c|c|c|}
\hline \multirow{2}{*}{ Time (hours) } & \multicolumn{2}{|c|}{$\mathrm{pH} 7.4$} & \multicolumn{2}{|c|}{ SGF } & \multicolumn{2}{|c|}{ pH 5.5} \\
\hline & {$\left[\mathrm{A}^{*}\right]$} & $\log [\mathrm{A}]$ & {$[\mathrm{A}]$} & $\log [\mathrm{A}]$ & {$[\mathrm{A}]$} & $\log [\mathrm{A}]$ \\
\hline 0 & 14.498 & 1.161308 & 15.912 & 1.201725 & 15.658 & 1.194736 \\
\hline 0.5 & 14.223 & 1.152991 & 15.601 & 1.193152 & 15.586 & 1.192735 \\
\hline 1 & 14.134 & 1.150265 & 15.41 & 1.187803 & 15.223 & 1.1825 \\
\hline 2 & 13.895 & 1.142859 & 14.423 & 1.159056 & 15.409 & 1.187774 \\
\hline 3 & 13.872 & 1.142139 & 13.975 & 1.145352 & 15.542 & 1.191507 \\
\hline 4 & 13.697 & 1.136625 & 13.53 & 1.131298 & 15.171 & 1.181014 \\
\hline 5 & 13.712 & 1.137101 & 13.052 & 1.115677 & 15.315 & 1.185117 \\
\hline 6 & 14.099 & 1.149188 & 13.04 & 1.115278 & 15.367 & 1.186589 \\
\hline 7 & 13.966 & 1.145072 & 12.88 & 1.109916 & 15.754 & 1.197391 \\
\hline 8 & 14.208 & 1.152533 & 12.675 & 1.102948 & 15.998 & 1.204066 \\
\hline
\end{tabular}

${ }^{*} \mathrm{~A}$ is for pro-NP.

TABLE 8: The calculated rate constants and half-lives.

\begin{tabular}{lcc}
\hline $\mathrm{pH}$ & $K_{\text {obs }}\left(\right.$ hour $\left.^{-1}\right)$ & $T_{1 / 2}$ (hours) \\
\hline 1.2 & $2.951 \times 10^{-2}$ & 23.479 \\
5.5 & $2.6 \times 10^{-3}$ & 262.0067 \\
7.4 & $2.075 \times 10^{-3}$ & 333.946 \\
\hline
\end{tabular}

\section{Conflicts of Interest}

The authors declare that there are no conflicts of interest regarding the publication of this paper.

\section{References}

[1] V. Lohar, S. Singhal, and V. Arora, "Prodrug: approach to better drug delivery," International Journal of Pharmaceutical Research, vol. 4, no. 1, pp. 15-21, 2012.

[2] T. Elsaman, O. A. A. Aldeeb, T. Aboul-Fadl, and E. I. Hamedelneil, "Synthesis, characterization and pharmacological evaluation of certain enzymatically cleavable NSAIDs amide prodrugs," Bioorganic Chemistry, vol. 70, pp. 144-152, 2017.

[3] A. M. Qandil, "Prodrugs of nonsteroidal anti-inflammatory drugs (NSAIDs), more than meets the eye: A critical review," International Journal of Molecular Sciences, vol. 13, no. 12, pp. 17244-17274, 2012.

[4] P. K. Halen, P. R. Murumkar, R. Giridhar, and M. R. Yadav, "Prodrug designing of NSAIDs," Mini-Reviews in Medicinal Chemistry, vol. 9, no. 1, pp. 124-139, 2009.

[5] S. Kumar, D. K. Tyagi, and A. Gupta, "Synthesis, characterization and pharmcological activity of ester prodrugs of naproxen," Asian Journal of Pharmaceutical and Clinical Research, vol. 3, no. 3, pp. 208-211, 2010.

[6] P. C. Sharma, S. Yadav, R. Pahwa, D. Kaushik, and S. Jain, "Synthesis and evaluation of novel prodrugs of naproxen," Medicinal Chemistry Research, vol. 20, no. 5, pp. 648-655, 2011.

[7] T. Elsaman and M. M. Ali, "Nonsteroidal anti-inflammatory drugs ( NSAIDs ) derivatives with anti-cancer activity," American Journal of Research Communication, vol. 4, no. 4, 2016.

[8] L. F. Wang, H. N. Chiang, and W. B. Chen, "Synthesis and properties of a naproxen polymeric prodrug," Journal of Pharmacy and Pharmacology, vol. 54, no. 8, pp. 1129-1135, 2002.
[9] V. R. Shanbhag, A. M. Crider, R. Gokhale, A. Harpalani, and R. M. Dick, "Ester and amide prodrugs of ibuprofen and naproxen: Synthesis, anti-inflammatory activity, and gastrointestinal toxicity," Journal of Pharmaceutical Sciences, vol. 81, no. 2, pp. 149154, 1992.

[10] J. Deb, J. Majumder, S. Bhattacharyya, and S. S. Jana, "A novel naproxen derivative capable of displaying anti-cancer and antimigratory properties against human breast cancer cells," $B M C$ Cancer, vol. 14, no. 1, article no. 567, 2014.

[11] H. Azizian, Z. Mousavi, H. Faraji et al., "Arylhydrazone derivatives of naproxen as new analgesic and anti-inflammatory agents: Design, synthesis and molecular docking studies," Journal of Molecular Graphics and Modelling, vol. 67, pp. 127-136, 2016.

[12] M. Thing, Y. Lu, L. Ågårdh et al., "Prolonged naproxen joint residence time after intra-articular injection of lipophilic solutions comprising a naproxen glycolamide ester prodrug in the rat," International Journal of Pharmaceutics, vol. 451, no. 1-2, pp. 3440, 2013.

[13] J. Rautio, T. Nevalainen, H. Taipale et al., "Piperazinylalkyl prodrugs of naproxen improve in vitro skin permeation," European Journal of Pharmaceutical Sciences, vol. 11, no. 2, pp. 157-163, 2000.

[14] C. Larsen, "Quantitative determination of dextran-naproxen ester pro-drugs with varying molecular weights and degrees of substitution in biological media by means of high-performance size exclusion chromatography with fluorescence detection," Journal of Pharmaceutical and Biomedical Analysis, vol. 7, no. 10, pp. 1173-1181, 1989.

[15] M. Sheha, A. Khedr, and H. Elsherief, "Biological and metabolic study of naproxen-propyphenazone mutual prodrug," European Journal of Pharmaceutical Sciences, vol. 17, no. 3, pp. 121-130, 2002.

[16] M. H. Helal, S. Y. Abbas, M. A. Salem, A. A. Farag, and Y. A. Ammar, "Synthesis and characterization of new types of 2-(6-methoxy-2-naphthyl) propionamide derivatives as potential antibacterial and antifungal agents," Medicinal Chemistry Research, vol. 22, no. 11, pp. 5598-5609, 2013.

[17] M. Spadaro, A. Bucolo, C. Ronsisvale, and G. Pappalardo, "Design, synthesis and antiinflammatory activity of novel alfa -tocopherol," Journal of Pharmaceutical Sciences and Research, vol. 1, no. 4, pp. 88-95, 2009. 
[18] G. Forte, I. Chiarotto, I. Giannicchi et al., "Characterization of naproxen-polymer conjugates for drug-delivery," Journal of Biomaterials Science, Polymer Edition, vol. 27, no. 1, pp. 69-85, 2016.

[19] M. Najlah, S. Freeman, D. Attwood, and A. D’Emanuele, "Synthesis, characterization and stability of dendrimer prodrugs," International Journal of Pharmaceutics, vol. 308, no. 1-2, pp. 175$182,2006$.

[20] T. Aboul-Fadl, T. Elsaman, O. A. Al-Deeb, H. A. Ghabbour, C. S. C. Kumar, and H.-K. Fun, "Some new NSAIDs prodrugs: an efficient synthesis, spectral characterization and X-ray crystal structure studies," Asian Journal of Chemistry, vol. 26, no. 16, pp. 5249-5254, 2014.

[21] ICH, Stability Testing of New Drug Substances and Products Q1A(R2), Int. Conf. Harmon, no. February, 2003.

[22] S. Niazi, Handbook of Pharmaceutical Manufacturing Formulations, CRC Press, 2009.

[23] ICH., ICH, Validation of Analytical Procedures: Text and Methodology, Int. Conf. Harmon, no. November, 1996. 

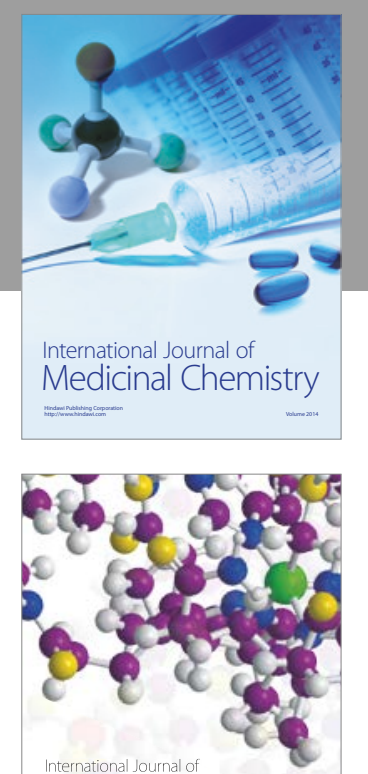

Carbohydrate Chemistry

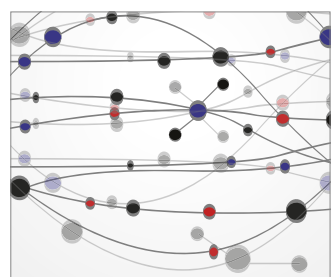

The Scientific World Journal
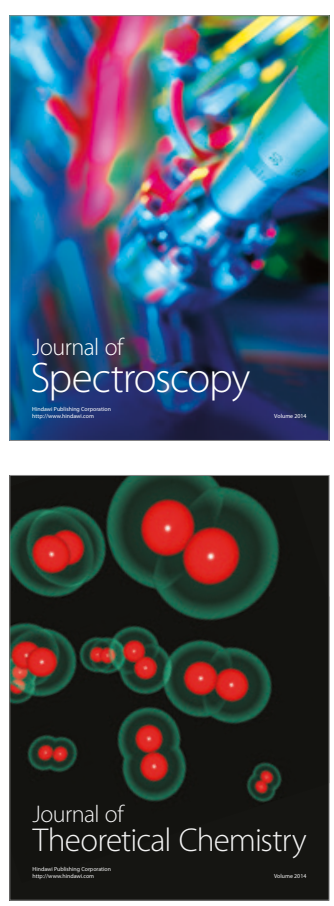
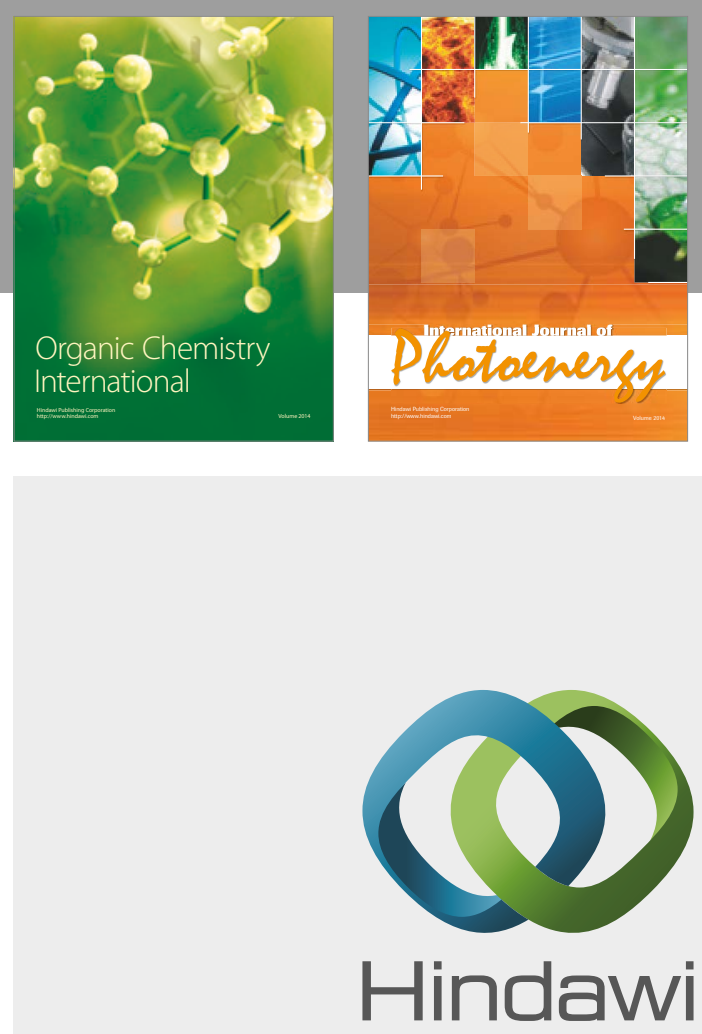

Submit your manuscripts at

https://www.hindawi.com

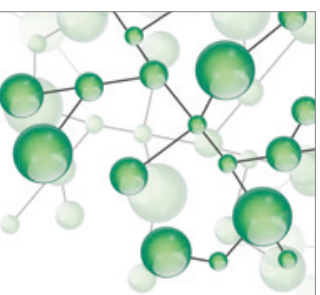

International Journal of

Inorganic Chemistry

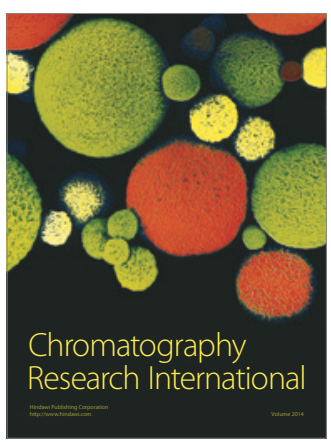

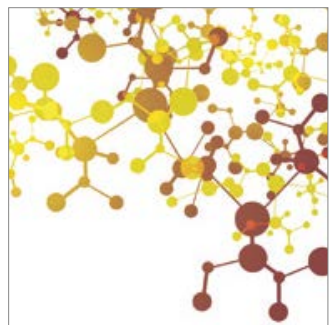

Applied Chemistry
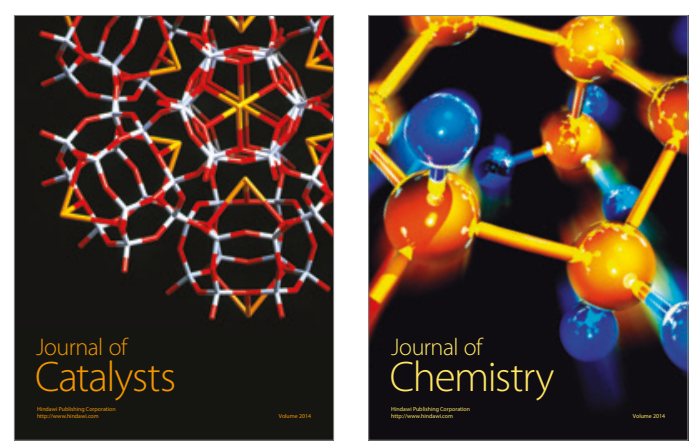
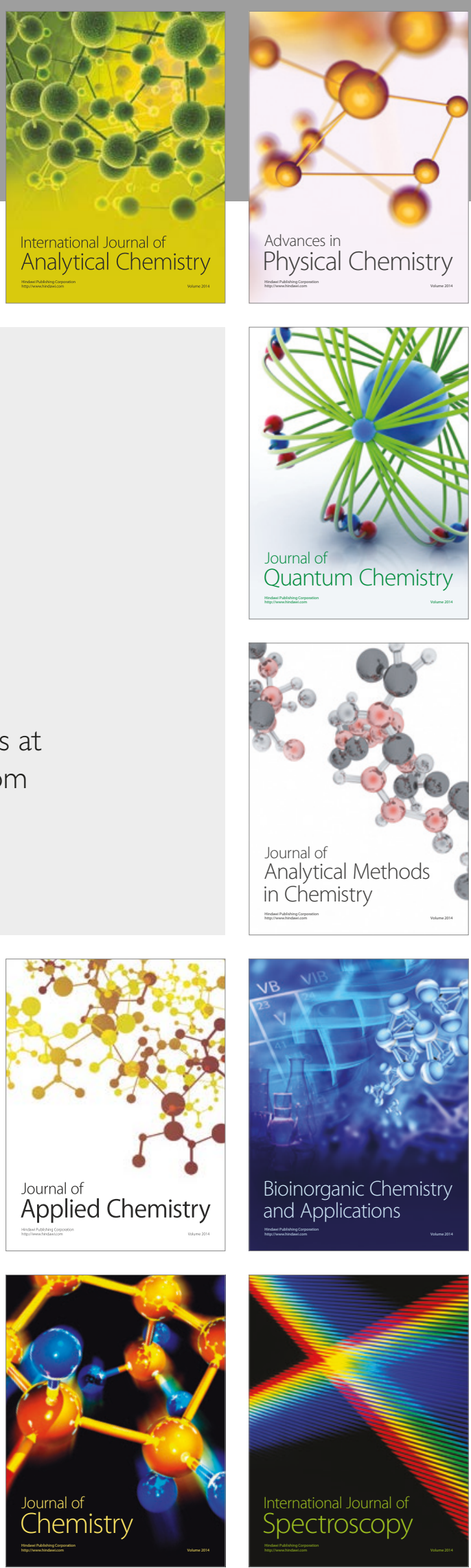